\title{
The Effect of Alluvial Foundation on the Earth Dams Settlement
}

\author{
Masoud Ghaemi ${ }^{1}$, Kaveh Ahangari ${ }^{1}$, Ali Noorzad ${ }^{2}$, Kamran Goshtasbi $^{3}$ \\ ${ }^{1}$ Department of Mining Engineering, Science and Research Branch, Islamic Azad University, Tehran, Iran \\ ${ }^{2}$ Faculty of Water and Environmental Engineering, Shahid Beheshti University, Tehran, Iran \\ ${ }^{3}$ Faculty of Mining Engineering, Tarbiat Modares University, Tehran, Iran \\ Email:*ahangari@srbiau.ac.ir,m.ghaemi65@gmail.com
}

How to cite this paper: Ghaemi, M., Ahangari, K., Noorzad, A. and Goshtasbi, K. (2017) The Effect of Alluvial Foundation on the Earth Dams Settlement. Open Journal of Geology, 7, 360-373. https://doi.org/10.4236/ojg.2017.73025

Received: January 9, 2017

Accepted: March 27, 2017

Published: March 30, 2017

Copyright (c) 2017 by authors and Scientific Research Publishing Inc. This work is licensed under the Creative Commons Attribution International License (CC BY 4.0).

http://creativecommons.org/licenses/by/4.0/ (c) (i) Open Access

\begin{abstract}
Careful monitoring in the earth dams, to measure deformation caused by settlement and movement has always been a concern for engineers in the field. In order to measure settlement and deformation of earth dams, usually the precision instruments of settlement set and combined Inclinometer that is commonly referred to IS instrument, will be used. In some dams, because the thickness of alluvium is high and there is no possibility of alluvium removal (technically and economically and in terms of performance), there is no possibility to place the end of IS instrument (precision instruments of Inclinometer-settlement set) in the rock foundation. Inevitably, have to accept installing pipes in the weak and the deformable alluvial foundation that this leads to errors in the calculation of the actual settlement (absolute settlement) in different parts of the dam body. The purpose of this paper is to present new and refine criteria for predicting settlement and deformation in earth dams. The study is based on conditions in three dams with a deformation quite alluvial (Agh Chai, Narmashir and Gilan-e Gharb) to provide settlement criteria affected by alluvial foundation. To achieve this goal, the settlement of dams was simulated by using finite difference method with FLAC3D software and then the modeling results were compared with reading IS instrument. In the end, the caliber of the model and validate the results, by using regression analysis techniques and scrutinized modeling parameters with real situations and then by using MATLAB software and Curve Fitting Toolbox, a new criteria for the settlement based on elasticity modulus, cohesion, friction angle, density of earth dam and alluvial foundation was obtained. The results of these studies show that, by using the new criteria measures, the amount of settlement and deformation for the dams with alluvial foundation can be corrected after instrument readings and the error rate in reading IS instrument can be greatly reduced.
\end{abstract}




\section{Keywords}

Earth Dam, Alluvial Foundation, Settlement, Finite Difference, FLAC3D, MATLAB, Curve Fitting, Refine Criteria, IS Instrument

\section{Introduction}

There are always parameters in the design of earth dams that are considered the leading cause of dam design, including leakage, settlement, and permeability, type of spillway and dynamic resistance of the dam are considered the important parameters of the dam [1].

Perhaps it can be said that among aforementioned parameters, the importance of settlement and deformation is an important factor in the behavior of the dam during construction, impounding dam and in operational stage. In order to measure settlement and horizontal deformation of dams usually the precision instruments of settlement set and combined Inclinometer that is commonly referred to IS instrument, will be used [2]. Installing IS instrument (Inclinometersettlement set) in the rock foundation of earth dams with alluvial layers in fixed point or in other words, to determine the point at which the movement or deformation of the pipes will be zero in it, is very difficult. In terms of another, because of the correct placement of IS instrument in the bedrock, the results are always relative; however, it is necessary to compare this reading with the base magnet to analyze settlement set reading. This question has also been raised that what is the appropriate criteria for the results of IS pipe, according to the different physical characteristics in the alluvial layers of dam foundation.

Many researchers and engineers have suggested different methods to analyze the settlement and horizontal deformation of the dam and they have divided them into five general groups that include: 1) numerically; 2) the experimental method; 3) instrumentation; 4) micro geodesy; 5) smart methods (Fuzzy Network, Neural Network, Genetic Algoritm [3]. Chrzanowski carried out the development of the first research on the analysis of the earth dam deformation. In mentioning research, the transformations were more considered caused by the stresses imposed on the dam body [4]. Kelaf, et al. were the first people that modeled an earthen dam in 1997 by using finite element method. He calculated the stress and strain in a gravel dam by using linear elastic behavior model [5].

Then Duncan, et al. in 1997 presented a few papers and introduced nonlinear hyperbolic model, a new behavioral model for settlement and deformation analysis of earth dams. [6] In their results, they indicated that the behavioral model provides results that are more realistic [7].

Marandi, M., et al., in 2012, tried to estimate the extent of settlement in dam crest by using GEP. They have studied on 30 dams in seven countries. The results showed that the method of GEP is able to estimate the dam crest settlement based on four characteristics: the porosity of the dam e, height $\mathrm{H}$, vertical deformation modulus $\mathrm{E}_{\mathrm{v}}$ and shape factor $\mathrm{Sc}$ [8]. 
In this regards, in this paper, first the evaluation and case studies of Geo-mechanical parameters will be discussed. After explaining the modeling and its steps in FLAC3D software, the settlement plots, and initial analysis of dams will be shown based on three intended history points, which respectively, include M1 (dam bottom), M2 (one third of the dam body height) and M3 (two thirds of the dam body height). In the following, preliminary modeling results will be compared with the instrumentation results of IS instrument and in the next step, after determining the deviation parameters for numerical modeling, modeling parameters will be reviewed by using back analysis technique. Finally, by using the MATLAB and Curve Fitting Toolbox [9], a new equation will be presented for correction values settlement of earth dam, with alluvial foundation, based on the basic parameters of the earth dams [10].

\section{Evaluation of Case Studies}

As it was mentioned earlier, in this article, three case studies have been used to determine the criteria measures, that by modeling, it is included Agh Chai Dam, [11] Narmashir dam and Gilan-e Gharb dam. In addition, the main specifications of all three dams have been briefly brought in Table 1 . In addition, plan and longitudinal sections of all three dams have been respectively brought [12].

\section{Modeling Earth Dam and Foundation}

\subsection{Modeling Process}

In this part, modeling and the process are generally examined. According to the principles of numerical modeling as well as the fact dam, the dam modeling of Agh Chai, Narmashir and Gilan-e Gharb with Flac 3D program is as follows:

1) Determining the size, scope and number of meshes in dam geometry modeling;

2) Assign materials to different parts of the model (alluvium, foundation and the dam body);

Table 1. Main Specifications of Agh Chai dam, Narmashir dam and Gilan-e Gharb [10] [11] [12].

\begin{tabular}{|c|c|c|c|}
\hline \multirow{2}{*}{$\begin{array}{c}\text { Gilan-e } \\
\text { Gharb dam }\end{array}$} & \multirow{2}{*}{$\begin{array}{c}\text { Narmashir } \\
\text { dam }\end{array}$} & \multirow{2}{*}{ Agh Chai dam } & Project name \\
\hline & & & Specifications \\
\hline Earth dam & Rockfill dam & $\begin{array}{c}\text { Arch dam } \\
\text { embankment }\end{array}$ & Type of dam \\
\hline 60 & 108.5 & 111.5 & Dam height (m) \\
\hline 610 & 720 & 1240 & $X$ length of dam (m) \\
\hline 9 & 16 & 19 & The dam crest width $(\mathrm{m})$ \\
\hline 5 & 7.9 & 9.3 & $\begin{array}{l}\text { Embankment volume } \\
\text { (million cubic meters) }\end{array}$ \\
\hline 21.5 & 32 & 25 & Maximum thickness of alluvium (m) \\
\hline 2002 & 2004 & 2005 & Construction time \\
\hline
\end{tabular}


3) Reticulation of dam body, alluvial foundation and bedrock by 15 node triangular elements (plane strain condition);

4) Apply static initial and boundary conditions;

5) Create the initial stresses in foundation and alluvium dam;

6) Allocation and defining gravity;

7) Solving the model to achieve a basic balance;

8) Fix the displacement and speed in knots;

9) Construction of the dam body and overall solution to the stable conditions.

\subsection{Geomechanical Properties of Earth Dam}

In this part, the geomechanical properties of the earth dam, alluvial foundation and bedrock components have been surveyed, given the prevailing sandy texture and low clay content and rock foundation in the main specifications are in Tables 2-6 below.

Table 2. Geotechnical properties of components AghChay dam, Narmashir and Gilan-e Gharb [10] [11] [12].

\begin{tabular}{cccccc}
\hline \multirow{2}{*}{ Specifications } & & & \multicolumn{2}{c}{ Components of dam } \\
\hline \multirow{2}{*}{ Dam name } & Parameter & & unit & Core & Crust \\
\hline \multirow{5}{*}{ AghChay } & Particularly dry weight & dry & $\mathrm{kN} / \mathrm{m}^{3}$ & 17 & 21 \\
& Special saturated weight & sat & $\mathrm{kN} / \mathrm{m}^{3}$ & 18 & 22 \\
& Permeability & $k$ & $\mathrm{~cm} / \mathrm{s}$ & $10-6$ & $10-3$ \\
& Cohesion & $C$ & $\mathrm{kPa}$ & 28 & 1 \\
& Angle of friction & & $\mathrm{deg}$ & 25 & 42 \\
& Particularly dry weight & $\mathrm{dry}$ & $\mathrm{kN} / \mathrm{m}^{3}$ & 16 & 22 \\
& Special saturated weight & $\mathrm{sat}$ & $\mathrm{kN} / \mathrm{m}^{3}$ & 18 & 24 \\
& Permeability & $k$ & $\mathrm{~cm} / \mathrm{s}$ & $10-7$ & $10-3$ \\
& Cohesion & $C$ & $\mathrm{kPa}$ & 30 & 1.5 \\
& Angle of friction & & $\mathrm{deg}$ & 28 & 39 \\
& Particularly dry weight & $\mathrm{dry}$ & $\mathrm{kN} / \mathrm{m}^{3}$ & 15 & 24 \\
& Special saturated weight & $\mathrm{sat}$ & $\mathrm{kN} / \mathrm{m}^{3}$ & 16 & 25 \\
& Permeability & $k$ & $\mathrm{~cm} / \mathrm{s}$ & $10-8$ & $10-3$ \\
Gilan-e Gharb & Cohesion & $C$ & $\mathrm{kPa}$ & 28 & 1 \\
& Angle of friction & $\square$ & $\mathrm{deg}$ & 25 & 42 \\
& & & &
\end{tabular}

Table 3. The shear and bulk modulus in Agh Chai Dam, Narmashir and Gilan-e Gharb [10] [11] [12].

\begin{tabular}{ccccc}
\hline & Specifications & & \multicolumn{2}{c}{ Components of dam } \\
\hline Dam name & Parameter & unit & Core & Crust \\
AghChay & $\mathrm{Gm0}$ & $\mathrm{MPa}$ & 115 & 185 \\
& $\mathrm{~K}$ & $\mathrm{MPa}$ & 560 & 440 \\
Narmashir & $\mathrm{Gm} 0$ & $\mathrm{MPa}$ & 125 & 170 \\
& $\mathrm{~K}$ & $\mathrm{MPa}$ & 550 & 410 \\
Gilan-e Gharb & $\mathrm{Gm} 0$ & $\mathrm{MPa}$ & 110 & 190 \\
& $\mathrm{~K}$ & $\mathrm{MPa}$ & 620 & 515 \\
\hline
\end{tabular}


Table 4. The Geotechnical properties of alluvial foundation in the Agh Chai dam [10].

\begin{tabular}{cccccc}
\hline Specifications & \multicolumn{5}{c}{ Depth (m) } \\
\hline Parameter & Unit & $0-5$ & $5-10$ & $10-15$ & $15-25$ \\
Special weight & $\mathrm{kN} / \mathrm{m}^{3}$ & 17 & 18 & 19 & 19 \\
Relative density & $\%$ & 62 & 65 & 74 & 81 \\
The initial shear modulus & $\mathrm{MPa}$ & 65 & 87 & 110 & 140 \\
Shear modulus (after & $\mathrm{MPa}$ & 98 & 110 & 145 & 170 \\
construction of the dam) & $\mathrm{MPa}$ & 115 & 190 & 235 & 410 \\
Bulk modulus & $\mathrm{cm} / \mathrm{s}$ & $10-3$ & $10-3$ & $10-3$ & $10-3$ \\
Permeability & $\mathrm{kPa}$ & 0 & 0 & 0 & 0 \\
Cohesion & $\mathrm{deg}$. & 29 & 33 & 33 & 35 \\
Angle of friction & & & & &
\end{tabular}

Table 5. The Geotechnical properties of alluvial foundation in the Narmashir dam [11].

\begin{tabular}{cccccc}
\hline Specifications & \multicolumn{5}{c}{ Depth (m) } \\
\hline Parameter & Unit & $0-10$ & $10-20$ & $20-30$ & $30-32$ \\
Special weight & $\mathrm{kN} / \mathrm{m}^{3}$ & 14 & 16 & 17 & 18 \\
Relative density & $\%$ & 56 & 60 & 70 & 77 \\
The initial shear modulus & $\mathrm{MPa}$ & 92 & 98 & 124 & 155 \\
Shear modulus (after & $\mathrm{MPa}$ & 151 & 151 & 182 & 195 \\
construction of the dam) & $\mathrm{MPa}$ & 190 & 230 & 440 & 520 \\
Bulk modulus & $\mathrm{cm} / \mathrm{s}$ & $10-3$ & $10-3$ & $10-3$ & $10-3$ \\
Permeability & $\mathrm{kPa}$ & 0 & 0 & 0 & 0 \\
Cohesion & $\mathrm{deg}$. & 24 & 25 & 27 & 31 \\
Angle of friction & & & & & \\
\hline
\end{tabular}

Table 6. The Geotechnical properties of alluvial foundation in the Gilan-e Gharb dam [12].

\begin{tabular}{|c|c|c|c|c|c|}
\hline \multicolumn{2}{|l|}{ Specifications } & \multicolumn{4}{|c|}{ Depth (m) } \\
\hline Parameter & Unit & $0-5$ & $5-10$ & $10-15$ & $15-22$ \\
\hline Special weight & $\mathrm{KN} / \mathrm{m}^{3}$ & 13 & 14 & 14 & 15 \\
\hline Relative density & $\%$ & 48 & 52 & 55 & 58 \\
\hline The initial shear modulus & $\mathrm{MPa}$ & 80 & 87 & 110 & 142 \\
\hline $\begin{array}{c}\text { Shear modulus (after } \\
\text { construction of the dam) }\end{array}$ & $\mathrm{MPa}$ & 145 & 160 & 178 & 190 \\
\hline Bulk modulus & $\mathrm{MPa}$ & 160 & 210 & 300 & 350 \\
\hline Permeability & $\mathrm{cm} / \mathrm{s}$ & $10-3$ & $10-3$ & $10-3$ & $10-3$ \\
\hline Cohesion & $\mathrm{kPa}$ & 0 & 0 & 0 & 0 \\
\hline Angle of friction & deg. & 30 & 30 & 33 & 33 \\
\hline
\end{tabular}

To model the dam body, every three dams, along with alluvial foundation and bedrock have taken place as an effective stress analysis, together with analysis of consolidation. It should be noted that, for three-dimensional modeling of all three dams, Fish functions in software FLAC3D was used and a complete coding 
has been done, which is very difficult and time-consuming, because it does not have a default like tunnel modeling, so the built models are time-consuming and difficult because of coding. In this model, behavior criteria taken into account for modeling the dams are hardening Soil Model, because the hardening soil model is an advanced Elasto-plastic model to simulate the behavior of different soils contains both soft soils and hard soils, in other words, it is not-united Mohr-Coulomb model. In fact, Mohr-Coulomb major disadvantages will be resolved by adding a cap level to model the pulp flow under the identical stresses, and pulb flow expression before crash with identical hardening law enforcement [13]. Then, for example, the construction of the Narmashir dam has been done as shown in Figures 1-4.

\subsection{Back Analysis}

After the initial modeling, the results are compared with installed instrumentation. It should be noted that for this purpose, the results of the three settlement sets at the bottom of the dam body, one-third and two-thirds of the dam height are taken into account for all three dams (can be seen in Table 7). The same corresponding points are installed based on the points $X, Y, Z$, the points are de-

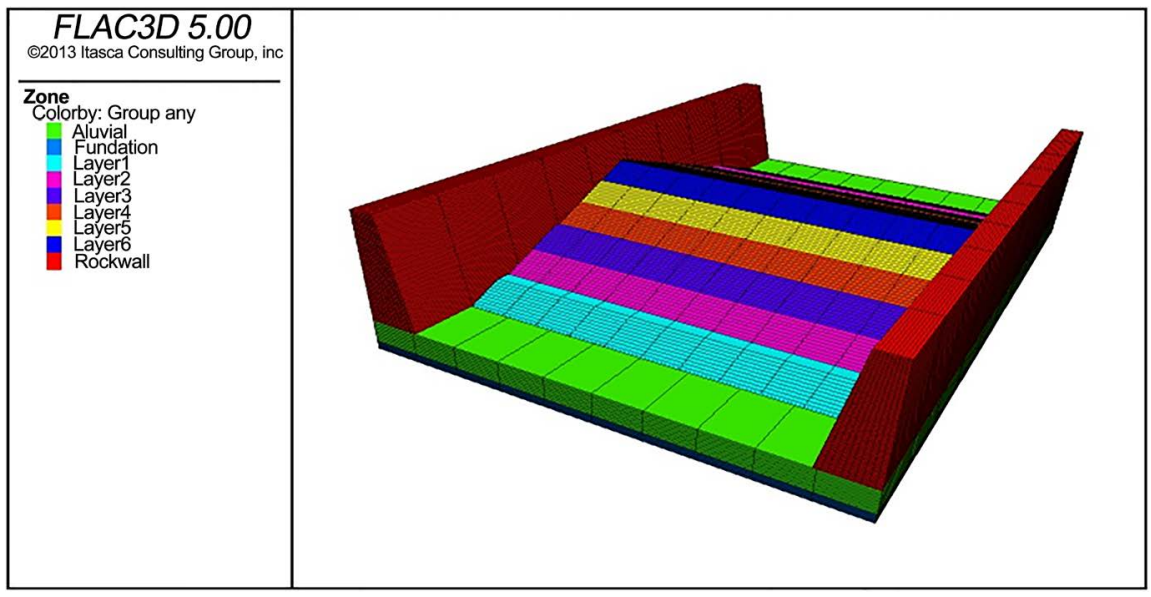

Figure 1. The alluvial and layer foundation modeling of the Narmashir dam.

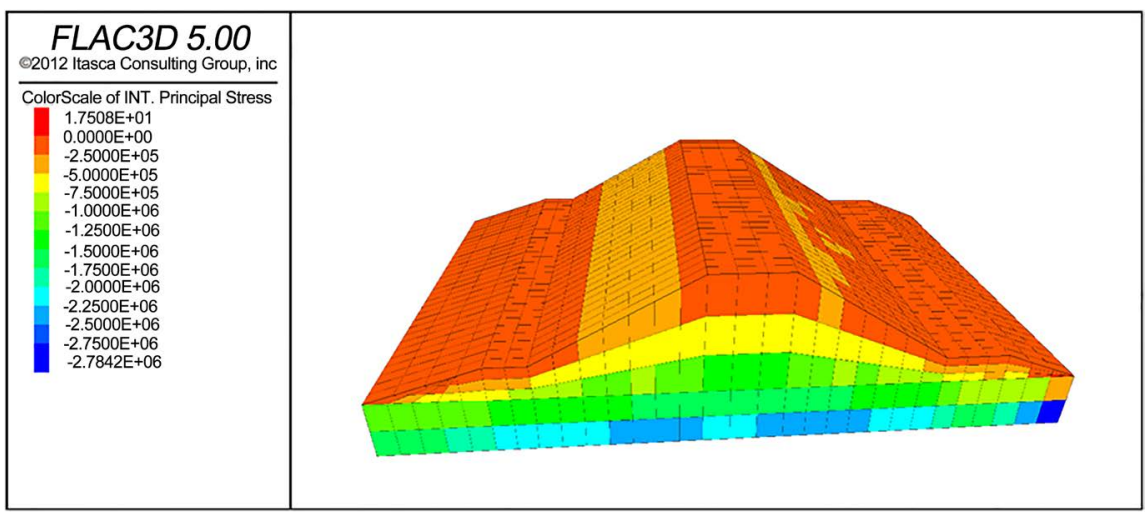

Figure 2. Contour of Z-Displacement in the Narmashir dam. 


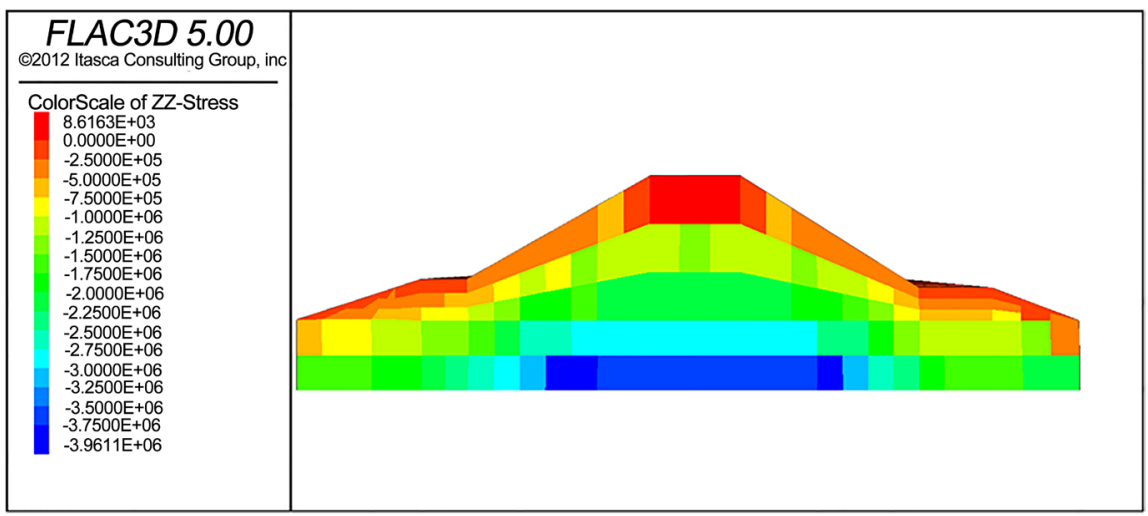

Figure 3. Initial Balance of Narmashir dam structure.

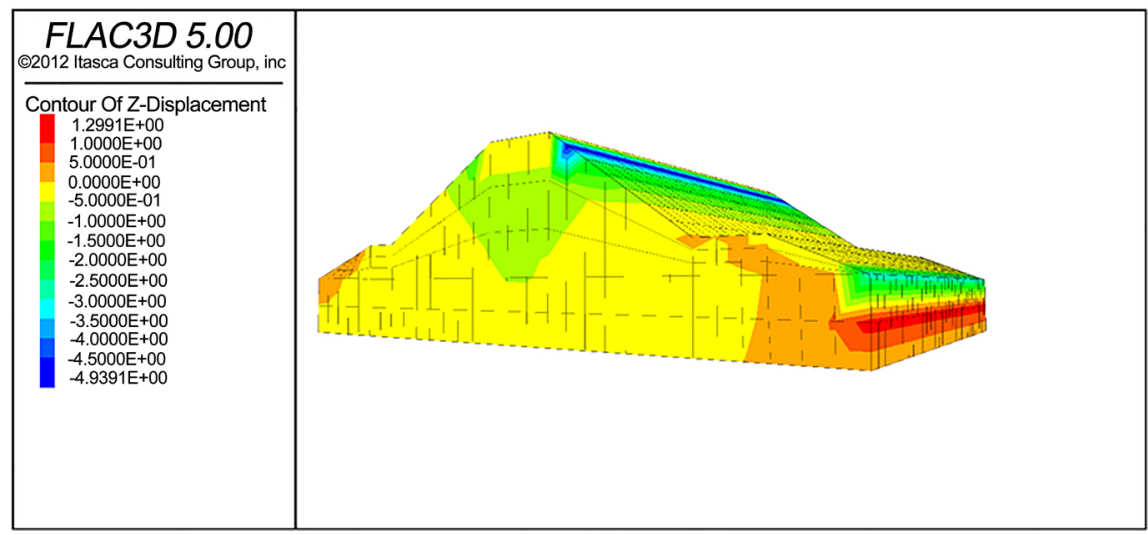

Figure 4. Determination of the general settlement in the Narmashir dam.

Table 7. Position of IS instrument installed in every three dams AghChay, Narmashir and Gilan-e Gharb [10] [11] [12].

\begin{tabular}{|c|c|c|c|c|}
\hline $\begin{array}{l}\text { Dam } \\
\text { Name }\end{array}$ & Parameter & $\begin{array}{c}\text { Installation } \\
\text { position }\end{array}$ & $\begin{array}{c}\text { Installation } \\
\text { balance }\end{array}$ & Section \\
\hline \multirow{3}{*}{ AghChay } & $M 1$ Bottom & downstream & 0 & 11 \\
\hline & $M 2$ A third of dam body height & downstream & 39 & 11 \\
\hline & $M 3$ Two third of dam body height & downstream & 76 & 11 \\
\hline \multirow{3}{*}{ Narmashir } & $M 1$ Bottom & Upstream & 0 & 13 \\
\hline & $M 2$ A third of dam body height & Upstream & 36 & 13 \\
\hline & M3Two third of dam body height & Upstream & 74 & 13 \\
\hline \multirow{3}{*}{$\begin{array}{l}\text { Gilan-e } \\
\text { Gharb }\end{array}$} & M1 Bottom & downstream & 1 & 17 \\
\hline & M2 A third of dam body height & downstream & 21 & 17 \\
\hline & M3 Two third of dam body height & downstream & 40 & 17 \\
\hline
\end{tabular}

fined in the modeling and you can see the exact coordinates in Table 8 and the results of modeling are compared with instrumentation which the results can be seen in Table 9.

In the following, in the Tables $10-14$, by changing the parameters, the modeling results are presented in tables after the back analysis.

Finally, modeling results after back analysis are reviewed and they are presented at the Table 15 below. 
Table 8. Position of history points in modeling dams AghChay, Narmashir and Gilan-e Gharb.

\begin{tabular}{|c|c|c|c|c|}
\hline \multirow{2}{*}{ Dam Name } & \multirow{2}{*}{ Parameter } & \multicolumn{3}{|c|}{ Coordinate Coordinate Coordinate } \\
\hline & & $X$ & $Y$ & $Z$ \\
\hline \multirow{3}{*}{ AghChay } & $M 1$ Bottom & 122.3 & 17.34 & 26 \\
\hline & $M 2$ A third of dam body height & 122.3 & 17.34 & 63 \\
\hline & $M B$ Two third of dam body height & 122.3 & 17.34 & 99 \\
\hline \multirow{3}{*}{ Narmashir } & $M 1$ Bottom & 240.2 & 56 & 32 \\
\hline & $M 2$ A third of dam body height & 240.2 & 56 & 68 \\
\hline & M3Two third of dam body height & 240.2 & 56 & 104 \\
\hline \multirow{3}{*}{$\begin{array}{l}\text { Gilan-e } \\
\text { Gharb }\end{array}$} & $M 1$ Bottom & 78 & 44 & 22 \\
\hline & M2 A third of dam body height & 78 & 44 & 52 \\
\hline & M3Two third of dam body height & 78 & 44 & 62 \\
\hline
\end{tabular}

Table 9. Compare the settlement of the results between Instrumentation and Modeling.

\begin{tabular}{cccc}
\hline Dam Name & Parameter & $\begin{array}{c}\text { The settlement set of } \\
\text { Instrumentation }(\mathrm{cm})\end{array}$ & $\begin{array}{c}\text { The settlement } \\
\text { Modeling }(\mathrm{cm})\end{array}$ \\
\hline \multirow{3}{*}{ AghChay } & $M$ 1 Bottom & 40 & 17 \\
& $M 2$ A third of dam body height & 65 & 34 \\
& $M 3$ Two third of dam body height & 91 & 68 \\
Narmashir & $M 2$ A third of dam body height & 35 & 11 \\
& MBTwo third of dam body height & 46 & 16 \\
Gilan-e & M1 Bottom & 58 & 5 \\
Gharb & M2 A third of dam body height & 15 & 15 \\
& $M 3$ Two third of dam body height & 33 & 19 \\
\hline
\end{tabular}

Table 10. Geotechnical properties of the dam components AghChay, Narmashir and Gilan-e Gharb after back analysis.

\begin{tabular}{cccccc}
\hline \multirow{2}{*}{ Features } & & & \multicolumn{2}{c}{ Dam Components } \\
\hline \multirow{2}{*}{ Dam Name } & Parameter & & Unit & Core & Crust \\
\hline & Unit Weight(dry) & $\square$ dry & $\mathrm{kN} / \mathrm{m}^{3}$ & 16.5 & 20 \\
& Unit Weight(saturated) & $\square$ sat & $\mathrm{kN} / \mathrm{m}^{3}$ & 17.2 & 21 \\
AghChay & Permeability & $\mathrm{k}$ & $\mathrm{cm} / \mathrm{s}$ & $10-7$ & $10-3$ \\
& Cohesion & $\mathrm{C}$ & $\mathrm{kPa}$ & 19 & 1 \\
& Friction Angle & & $\mathrm{deg}$ & 19 & 28 \\
& Unit Weight(dry) & $\mathrm{dry}$ & $\mathrm{kN} / \mathrm{m}^{3}$ & 13 & 18 \\
Narmashir & Unit Weight(saturated) & $\mathrm{sat}$ & $\mathrm{kN} / \mathrm{m}^{3}$ & 16 & 21 \\
& Permeability & $\mathrm{k}$ & $\mathrm{cm} / \mathrm{s}$ & $10-7$ & $10-3$ \\
& Cohesion & $\mathrm{C}$ & $\mathrm{kPa}$ & 24 & 1 \\
& Friction Angle & & $\mathrm{deg}$ & 22 & 31 \\
& Unit Weight(dry) & $\mathrm{dry}$ & $\mathrm{kN} / \mathrm{m}^{3}$ & 9 & 19 \\
& Unit Weight(saturated) & $\square \mathrm{sat}$ & $\mathrm{kN} / \mathrm{m}^{3}$ & 13 & 18 \\
Gilan-e & Permeability & $\mathrm{k}$ & $\mathrm{cm} / \mathrm{s}$ & $10-9$ & $10-3$ \\
Gharb & Cohesion & $\mathrm{C}$ & $\mathrm{kPa}$ & 16 & 1 \\
& Friction Angle & & $\mathrm{deg}$ & 17 & 23 \\
\hline & & & & &
\end{tabular}


Table 11. Shear modulus and the Balkans of Agh Chai, Narmashir and Gilan-e Gharb Dam after back analysis.

\begin{tabular}{ccccc}
\hline & Features & & \multicolumn{2}{c}{ Dam Components } \\
\hline Dam Name & Parameter & Unit & Core & Crust \\
AghChay & Gm0 & $\mathrm{MPa}$ & 105 & 165 \\
& $\mathrm{~K}$ & $\mathrm{MPa}$ & 515 & 410 \\
Narmashir & $\mathrm{Gm} 0$ & $\mathrm{MPa}$ & 110 & 130 \\
& $\mathrm{~K}$ & $\mathrm{MPa}$ & 510 & 390 \\
Gilan-e Gharb & $\mathrm{Gm} 0$ & $\mathrm{MPa}$ & 90 & 170 \\
& $\mathrm{~K}$ & $\mathrm{MPa}$ & 585 & 490 \\
\hline
\end{tabular}

Table 12. Geotechnical properties of AghChay alluvial foundation, after back analysis.

\begin{tabular}{cccccc}
\hline \multicolumn{1}{c}{ Features } & \multicolumn{5}{c}{ Depth (m) } \\
\hline $\begin{array}{c}\text { Parameter } \\
\text { Special weight }\end{array}$ & $\mathrm{Unit}$ & $0-5$ & $5-10$ & $10-15$ & $15-25$ \\
$\begin{array}{c}\text { Relative density } \\
\text { The initial shear } \\
\text { modulus }\end{array}$ & $\%$ & 15 & 16 & 17 & 17 \\
$\begin{array}{c}\text { Shear modulus (after } \\
\text { construction of the dam) }\end{array}$ & $\mathrm{MPa}$ & 62 & 85 & 107 & 137 \\
$\begin{array}{c}\text { Bulk modulus } \\
\text { Permeability }\end{array}$ & $\mathrm{MPa}$ & 95 & 107 & 142 & 167 \\
Cohesion & $\mathrm{cm} / \mathrm{s}$ & $4-10$ & $4-10$ & $4-10$ & $4-10$ \\
Angle of friction & $\mathrm{kPa}$ & 0 & 0 & 0 & 0 \\
& $\mathrm{deg}$. & 25 & 29 & 29 & 31 \\
\hline
\end{tabular}

Table 13. Geotechnical properties of Narmashir alluvial foundation, after back analysis.

\begin{tabular}{cccccc}
\hline Features & \multicolumn{5}{c}{ Depth (m) } \\
Parameter & Unit & $0-10$ & $10-20$ & $20-30$ & $30-32$ \\
Special weight & $\mathrm{kN} / \mathrm{m}^{3}$ & 12 & 14 & 15 & 16 \\
$\begin{array}{c}\text { Relative density } \\
\text { The initial shear modulus }\end{array}$ & $\mathrm{MPa}$ & 85 & 92 & 129 & 151 \\
$\begin{array}{c}\text { Shear modulus (after } \\
\text { construction of the dam) }\end{array}$ & $\mathrm{MPa}$ & 145 & 145 & 176 & 189 \\
$\begin{array}{c}\text { Bulk modulus } \\
\text { Permeability }\end{array}$ & $\mathrm{MPa}$ & 180 & 224 & 431 & 511 \\
Cohesion & $\mathrm{cm} / \mathrm{s}$ & $10-3$ & $10-3$ & $10-3$ & $10-3$ \\
Angle of friction & $\mathrm{kPa}$ & 0 & 0 & 0 & 0 \\
\hline
\end{tabular}

\section{Presenting Settlement Equation by Using a Curve Fitting Toolbox}

Refine Criteria obtained in this study is designed by using MATLAB software. The database of three dams is considered that is the measure of the same information. It should be noted that in the Curve Fitting Toolbox, only three va- 
riables could be used to input data to the Toolbox. That is why by multiplication and division operations on input data, the number of variables became two main parameters, namely A and B. A parameter was inserted as the first input and parameter $\mathrm{B}$ was inserted as the second input and the results of the settlement were inserted as the third input. In the same way, it was applied to obtain the settlement of Dam bottom (M1), the settlement in one third of the dam body height (M2), the settlement in two-thirds of the dam body height (M3). Select basis of exposure parameters was the attempt and error, so that the highest correlation coefficient and the most optimized mode will be obtained. The used data are shown with maximum and minimum values in the Table 16.

To obtain better results, all data entries were normalized in the range of 0 to 1 by using the following equation. Then they were entered into the software

$$
N=\frac{(X-\operatorname{Min})}{(\operatorname{Max}-\operatorname{Min})}
$$

Table 14. Geotechnical properties of Gilan-e Gharb alluvial foundation, after back analysis.

\begin{tabular}{cccccc}
\hline Features & \multicolumn{5}{c}{ Depth (m) } \\
\hline Parameter & Unit & $0-5$ & $5-10$ & $10-15$ & $15-22$ \\
Special weight & $\mathrm{kN} / \mathrm{m}^{3}$ & 10 & 11 & 11 & 13 \\
Relative density & $\%$ & 42 & 48 & 48 & 51 \\
The initial shear modulus & $\mathrm{MPa}$ & 71 & 81 & 105 & 125 \\
Shear modulus (after & $\mathrm{MPa}$ & 140 & 155 & 175 & 185 \\
construction of the dam) & & & 202 & 196 & 346 \\
Bulk modulus & $\mathrm{MPa}$ & 145 & $10-3$ & $10-3$ & $10-3$ \\
Permeability & $\mathrm{cm} / \mathrm{s}$ & $10-3$ & 0 & 0 & 0 \\
Cohesion & $\mathrm{kPa}$ & 0 & 28 & 29 & 29 \\
Angle of friction & $\mathrm{deg}$. & 28 & & & \\
\hline
\end{tabular}

Table 15. Compare the settlement of the results between Instrumentation and Modeling after back analysis.

\begin{tabular}{|c|c|c|c|}
\hline Dam Name & Parameter & $\begin{array}{l}\text { The settlement set of the } \\
\text { Instrumentation }(\mathrm{cm})\end{array}$ & $\begin{array}{l}\text { The settlement } \\
\text { Modeling }(\mathrm{cm})\end{array}$ \\
\hline \multirow{3}{*}{ AghChay } & M1 Bottom & 40 & 40 \\
\hline & M2 A third of dam body height & 65 & 62 \\
\hline & M3 Two third of dam body height & 91 & 87 \\
\hline \multirow{3}{*}{ Narmashir } & M1 Bottom & 35 & 35 \\
\hline & M2 A third of dam body height & 46 & 42 \\
\hline & M3Two third of dam body height & 58 & 53 \\
\hline \multirow{3}{*}{$\begin{array}{l}\text { Gilan-e } \\
\text { Gharb }\end{array}$} & M1 Bottom & 15 & 15 \\
\hline & M2 A third of dam body height & 28 & 26 \\
\hline & M3Two third of dam body height & 33 & 32 \\
\hline
\end{tabular}


Table 16. The lowest and highest values of used parameters.

\begin{tabular}{cccccc}
\hline Input & Unit & $\begin{array}{c}\text { Values } \\
\text { range }\end{array}$ & Input & Unit & $\begin{array}{c}\text { Values } \\
\text { range }\end{array}$ \\
\hline $\begin{array}{c}\text { Shear } \\
\text { modulus }\end{array}$ & $\mathrm{MPa}$ & $160-100$ & Height & $\mathrm{m}$ & $180-90$ \\
$\begin{array}{c}\text { Angle of } \\
\text { friction }\end{array}$ & $\mathrm{deg}$ & $50-20$ & Crest width & $\mathrm{m}$ & $22-12$ \\
$\begin{array}{c}\text { Cohesion } \\
\text { Bulk }\end{array}$ & $\mathrm{kg} / \mathrm{cm}^{2}$ & $18-1$ & Axial length & $\mathrm{m}$ & $1240-610$ \\
$\begin{array}{c}\text { modulus } \\
\text { Special } \\
\text { Weight }\end{array}$ & $\mathrm{MPa}$ & $590-400$ & $\begin{array}{c}\text { Porosity difference } \\
\text { Ratio of volume, on the } \\
\text { weight of dam }\end{array}$ & $\mathrm{m}^{3} /$ ton & $0-48-0.52$ \\
\hline
\end{tabular}

In the Curve Fitting Toolbox of $X$-axis, A parameter values were entered and in the $Y$-axis, $B$ parameter values and in the $Z$-axis, dam settlement values were entered. Detailed parameters of $A, B$ and the relation obtained from fitting these settlements of dam Bottom are as follows:

$$
\begin{gathered}
A 1=\frac{C_{f} \gamma_{f} k_{f}}{\varnothing_{f}}+\frac{C_{a} \gamma_{a} k_{a}}{\varnothing_{a}} \\
B 1=\frac{H}{B^{*} \nabla} * \frac{\Delta e_{f} * G_{f}}{O C R_{f}}+\frac{\Delta e_{a}^{*} G_{a}}{O C R_{a}}
\end{gathered}
$$

$H$ : Height of the dam $W$ : Width of the crown $C$ : Cohesion $\Delta e$ : porosity difference

$\gamma$. density $\nabla$ : volume to weight ratio of the Dam (cubic meters per tons) $K$ : bulk modulus

Rock foundation parameters of the dam values are shown in $f$ index, core parameter values of the dam are shown in $\mathrm{c}$ index and the values of the alluvium parameters are shown in an index

$$
M_{1}=-116.1+31.4 * A 1+1.149 * B 1
$$

$M 1$ : the dam Bottom settlement $(\mathrm{cm})$

To obtain the settlement in one third of the dam's dam body height, which means $M 2$ was acted as $M 1$ equation; input parameters are divided into two parameters of $A 2$, and $B 2$ that the details of which are as follows:

$$
\begin{gathered}
A 2=\frac{C_{f} \gamma_{f} k_{f}}{\varnothing_{f}}+\frac{C_{a} \gamma_{a} k_{a}}{\varnothing_{a}}+\frac{C_{c} \gamma_{c} k_{c}}{\varnothing_{c}} \\
B 2=\frac{H}{B * \nabla} * \frac{\Delta e_{f} * G_{f}}{O C R_{f}}+\frac{\Delta e_{a} * G_{a}}{O C R_{a}}+\frac{\Delta e_{c}^{*} G_{c}}{O C R_{c}} \\
M_{2}=18.33-1.135 * A 2+0.85 * B 2
\end{gathered}
$$

$M 2$ : The settlement in one third of the dam's dam body height $(\mathrm{cm})$

$$
\begin{gathered}
A 3=\frac{C_{f} \gamma_{f} k_{f}}{\varnothing_{f}}+\frac{C_{a} \gamma_{a} k_{a}}{\varnothing_{a}}+\frac{C_{c} \gamma_{c} k_{c}}{\varnothing_{c}}+\frac{C_{s} \gamma_{s} k_{s}}{\varnothing_{s}} \\
B 3=\frac{H}{B * \nabla} * \frac{\Delta e_{f} * G_{f}}{O C R_{f}}+\frac{\Delta e_{a}^{*} G_{a}}{O C R_{a}}+\frac{\Delta e_{c}^{*} G_{c}}{O C R_{c}}+\frac{\Delta e_{s}^{*} G_{s}}{O C R_{s}} \\
M_{3}=64.01-4.38 * A 3+1.26 * B
\end{gathered}
$$


M3: The settlement in the point near the dam crest $(\mathrm{cm})$

After calculating each prediction model, it is necessary to examine the ability and the power of different forecasting models. There are diverse criteria for evaluating the performance of different forecasting methods, however, in this study, to compare the prediction power, the average absolute error criteria, standard deviation, coefficient of determination and mean square error root are used in the Table 17. These criteria can be shown as Equations (11) to (14):

$$
\begin{gathered}
\sigma=\sqrt{\left(\frac{1}{n}\right) \sum_{i=1}^{n}\left(e_{i-} \bar{e}\right)^{2}} \\
\text { MAE }=\left(\frac{1}{n}\right) \sum_{i=1}^{n}\left|m_{i-} p_{i}\right| \\
R M S E=\sqrt{\left(\frac{1}{n}\right) \sum_{i=1}^{n}\left(m_{i-} p_{i}\right)^{2}} \\
R^{2}=\left(\frac{\sum_{i=1}^{n}\left(p_{i}-\bar{p}\right)\left(m_{i}-\bar{m}\right)}{\sum_{i=1}^{n}\left(p_{i}-\bar{p}\right)^{2} \sum_{i=1}^{n}\left(m_{i}-\bar{m}\right)^{2}}\right)^{2}
\end{gathered}
$$

Table 17 is according to the performance of the specified Equations in CURVE FITTING, which represents the accuracy and precision of equations. In addition, Table 17, will be taught based on the instrumentation information and it will calculate the errors in each equation.

\section{Discussion}

An equation is presented for dam's settlement in three points of close to the crown, half of the dam body height and the dam's bottom by using the collected data. Based on Equations 4, 7 and 10, dams' settlement of Agh Chai, Narmashir and Gilan-e Gharb was amended and results are shown in Table 18.

In addition, the results of performance obtained from the presented equations are shown in Figure 5 in comparison by using various criteria.

As network analysis results showed, the best correlation coefficient between the predicted settlement and settlement of instrumentation in the Curve Fitting of MATLAB software is related to the $M 1$ equation. It should be noted that the correlation coefficient between the instrumentation and predicted values is obtained by all three equations as according to all the data. The proposed equation can be used easily to estimate the settlement at minimum time for the dams with alluvium that with the use of it, the IS pipes readings can be corrected. To determine the amount of $M 1$ and other proposed equations ( $M 2 \&$ $M 3)$, it is trying to present an equation by trial and error that has the highest

Table 17. The statistics range of best fitting.

\begin{tabular}{ccccc}
\hline RMSE & Adjusted R-square & R-square & SSE & \\
\hline $\mathbf{0 . 0 3 2 3}$ & 0.986 & 0.987 & 0.038 & M1 \\
$\mathbf{0 . 0 9 6 3}$ & 0.864 & 0.8718 & 0.343 & M2 \\
$\mathbf{0 . 0 4 4}$ & 0.961 & 0.963 & 0.073 & M3 \\
\hline
\end{tabular}


Table 18. Compare the predicted values of settlement and calculated settlement.

\begin{tabular}{cccc}
\hline & Equation & Predicted settlement & $\begin{array}{c}\text { Calculated } \\
\text { settlement }\end{array}$ \\
\hline \multirow{3}{*}{ Agh Chai } & M1 & 20 & 21 \\
& M2 & 26 & 27 \\
Narmashir & M3 & 31 & 32 \\
& M1 & 28 & 29 \\
Gilan-e & M3 & 41 & 41 \\
Gharb & M1 & 56 & 57 \\
& M2 & 29 & 29 \\
& M3 & 41 & 43 \\
\end{tabular}

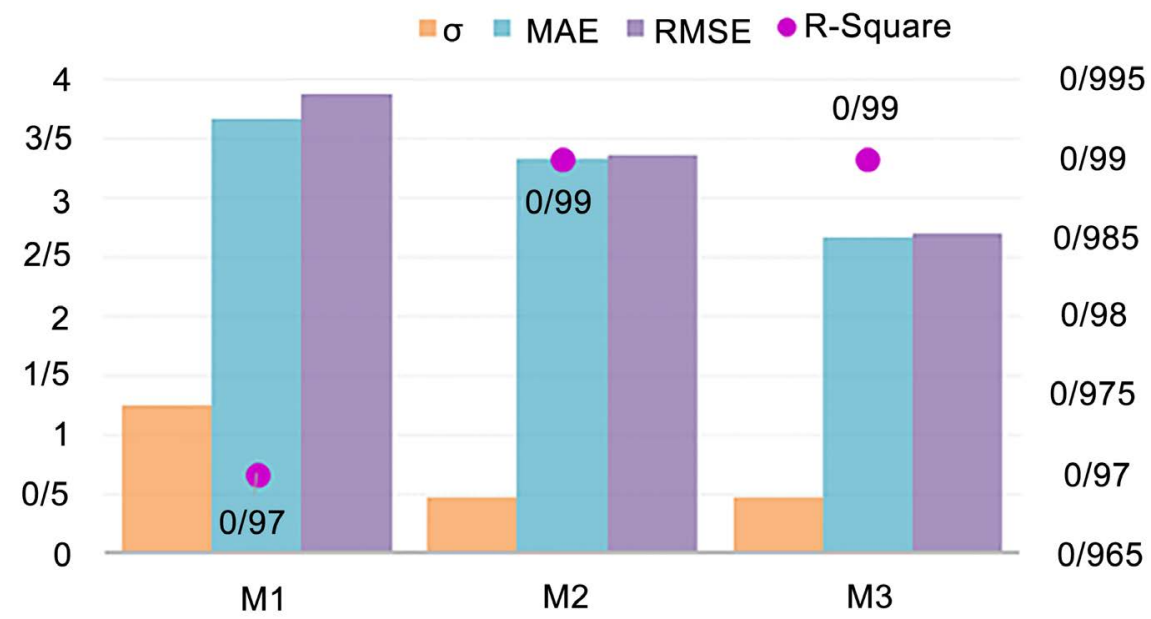

Figure 5. Comparison of different criteria for the presented equations.

correlation and the least amount of errors. Also, the presented equations should be closed to the objective function (reading results of instrumentation) in terms of accuracy.

\section{Conclusion}

In this study, it has been trying to compare the results of IS instrumentation readings, with the results of numerical modeling, based on behavioral models of hardening Mohr-Coulomb. The original modeling results indicated significant differences between numerical modeling and the IS instrumentation readings, which confirmed the reason of this research. The analysis indicated that alluvial is a major cause of error in modeling and causes the settlement to the dam body. By back analysis, more realistic parameters will be achieved for the behavior of dam materials as well as determining the behavior of parts that there is no information on their behavior, such as alluvium. With a good adaptation of instrumentation and numerical model, during construction and operation, we can 
predict actual behavior of the dam, in the future, with reasonable accuracy. Also, based on analysis on all three equations, it was found that the $M 1$ equation (as the bottom of the dam) had a better correlation coefficient than the equations of $M 2$ (as a third of the dam height) and $M 3$ (as two thirds of the dam height). The lowest average absolute error, mean square error root and sum of squares residual error were related to equation $M 1$. It is noted that this limitations presented equations, valid only until the construction of earth dams and also the earth dams that are only under static stress.

\section{References}

[1] Bell, F.G. (1995) Engineering Treatment of Dam. F.N. Spon, Durban.

[2] Ahangari, K., Moeinossadat, S.R., Behnia, D., Behnia, M. and Moeinossadat, S.H. (2012) Application of New Methods for Intelligent ANN, ANFIS and GEP for Predicting the Static Elasticity Modulus of Limerock. International Conference on Nonlinear Modeling \& Optimization, Shomal University, Amol, 28-29 August 2012.

[3] Chrzanowski, A., Chen, Y.Q. and Secord, J. (2007) Geometrical Analysis of Deformation Surveys. Proceedings (MIT), Deformation Measurements Workshop, MIT, Boston, 31 October-1 November 2007, 170-206.

[4] Chrzanowski, A., Chen, Y.Q. and Secord, J. (2008). On the Strain Analysis of Tectonic Movements Using Fault Crossing Geodetic Surveys. Tectonophysics, 97, 297-315.

[5] Chugh, A.K. and Falvey, H.T. (1978) A Computer Program for Planar Seepage Analysis in a Zoned Anisotropic Medium by the Boundary Element Method. Advances in Engineering Software, 5, 196-201.

[6] Duncan, J.M. (1997) State of the Art: Static Stability and Deformation Analysis. In: Seed, R.B. and Boulanger, R.W., Eds., Proceedings Specialty Conference on Stability and Performance of Slopes and Embankments II, ASCE, 222-266.

[7] Duncan, J.M. (1996) State of the Art: Limit Equilibrium and Finite-Element Analysis of Slopes, ASCE. Journal of Geotechnical Engineering, 122, 577-595.

[8] Marandi, M., Vaezinejad, M. and Khavari, E. (2012) Prediction Of Concrete Faced Rock Fill Dams Settlements Using Genetic Programming Algorithm. International Journal of Geoscience, 3, 601-609.

[9] Curve Fitting Toolbox-MATLAB. The Math Works Inc., Natick, Massachusetts.

[10] Final Technical Report, Second Phase Studies of AQCHAY Earth Dam (2003) Tehran, Consulting Engineering MAHAB QODS, Repot No. 19, 50-442.

[11] Final Technical Report, Second Phase Studies of Narmashir Earth Dam (2000) Tehran, Consulting Engineering MAHAB QODS, Repot No. 3, 720-2840.

[12] Final Technical Report, Second Phase Studies of GILANQARB Earth Dam (2001) Tehran, Consulting Engineering AB NIROU, Repot No. 3, 230-460.

[13] Itasca Consulting Group, Inc. (2004) FLAC3D User Manual: Version 5.0. USA. 
Submit or recommend next manuscript to SCIRP and we will provide best service for you:

Accepting pre-submission inquiries through Email, Facebook, LinkedIn, Twitter, etc. A wide selection of journals (inclusive of 9 subjects, more than 200 journals)

Providing 24-hour high-quality service

User-friendly online submission system

Fair and swift peer-review system

Efficient typesetting and proofreading procedure

Display of the result of downloads and visits, as well as the number of cited articles Maximum dissemination of your research work

Submit your manuscript at: http://papersubmission.scirp.org/

Or contact ojg@scirp.org 